\title{
PROBLEM ULOGE KRALJEVINE SRBIJE U SARAJEVSKOM ATENTATU I IZBIJANJU PRVOG SVJETSKOG RATA
}

\author{
Tihomir RAJČIĆ \\ OŠ kneza Mislava, Kaštel Sućurac \\ Split, Hrvatska
}

\author{
UDK: 94(497.6 Sarajevo)“1914“ \\ DOI: http://doi.org/10.21857/mnlqgc0gey \\ Prethodno priopćenje \\ Prihvaćeno: 23. veljače 2017.
}

Autor se u članku bavi ulogom Kraljevine Srbije u Sarajevskom atentatu i izbijanju Prvog svjetskog rata istražujući beogradsku obavještajnu mrežu u Bosni i Hercegovini u koju su bili upleteni konci beogradske vlade, vladine organizacije „Narodna odbrana“, organizacije kao "Crna ruka“, ali i organizacije „Mlada Bosna“, na koje su odlučno utjecali kontroverzni i nedovršeni reformski planovi austrougarskog prijestolonasljednika Franje Ferdinanda. U zaključku, autor ističe da se „razina odgovornosti“ Kraljevine Srbije ponajprije ogleda u sustavnom političkom zataškavanju svog udjela odgovornosti za Sarajevski atentat i europskoj političkoj krizi koja je uslijedila.

Ključne riječi: Kraljevina Srbija, sarajevski atentat, beogradska obavještajna mreža, Franjo Ferdinand.

\section{UVOD}

„Ipak, činjenica je, kao što ćemo vidjeti u nastavku da su austrijske optužbe protiv Srbije 1914., potvrđene dokazima sa suđenja, u stvari prije umjerena nego pretjerana procjena odgovornosti Srbije."

„Vlada Srbije pokazala je malo volje za pregovore s Bečom. U stvari, neki elementi beogradskog režima radili su na tome da, ugroze vladavinu Habsburgovaca u Bosni, čak i nasilnim sredstvima." ${ }^{2}$

„Što se više bliži 100. godišnjica od izbijanja Prvog svetskog rata, to su sve češći novi naslovi istorijskih radova kojima izdavači žele da je obeleže. Za razliku od ranijih godišnjica, ovu karakteriše pokušaj da se reinterpretira uloga Balkana, posebno Srbije u ključnim razlozima izbijanja rata. Deo produkcije karakteriše pokušaj namernog sklanjanja u stranu već utvrđenih činjenica o uticaju međuratne politike nemačkih vlada na skidanje odgovornosti za rat pod svaku cenu... . Kasnije u vreme raspada Jugoslavije devedesetih godina, razmišljajući o uzrocima srbofobije u američkim i zapadnim krugovima nalazio

Sidney Bradshaw Fay, The Origins of the World War, volume II., New York, 1928., 57.

2 Samuel R. Williamson, The Origins of World War I, Journal of Interdiscplinary History, svezak 17, br. 4, 1998., 795 . 
sam njihove korene $\mathrm{u}$ istorijskom austro-nemačko-srpskom sukobu koji je prethodio Prvom svetskom ratu.“"

„Beograd je bio potpuno svjestan opasnosti situacije i pokazao je jasnu volju za suradnjom. Istovremeno, oni na vlasti u Srbiji su bili skloni otezanju jer nisu htjeli raskrinkati Apisa, šefa tajne službe niti priznati da je, doslovno pred očima vlade, postojala tajna mreža koja je promicala jasan cilj uništenja Austro-Ugarske.“4

Ovi kronološki poredan odlomci iz historiografske literature koji premošćuju gotovo čitavo stoljeće svjedoče da je problem uloge Kraljevine Srbije u Sarajevskom atentatu i izbijanju Prvog svjetskog rata još uvijek predmet žustrih rasprava, odnosno da je daleko od razriješenog.

Zato je u istraživanju ovog problema potrebno promijeniti kut gledanja, na način kako su to učinili Jay Winter i Antonie Prost koji smatraju da zadnjih dvadesetak godina Prvi svjetski rat sve više počeo izgledati kao „europski građanski rat“ te da „sve države, svi narodi, u različitoj mjeri dijele odgovornost za katastrofu koju nisu bili u stanju predvidjeti i spriječiti... . Ono što je smatrano zločinom, postalo je kolektivna pogreška, čije elemente treba raspetljati da bi se shvatilo kako je do pogreške došlo".5

Jošje precizniji Christopher Clark koji smatra da je naša obveza razumjeti vanjske i unutrašnje sile koje su djelovale na srbijanske političare, časnike i obavještajne aktiviste umiješane u Sarajevski atentat. ${ }^{6} \mathrm{Na}$ tom tragu Sean McMeekin smatra da je u kontekstu događaja koji su doveli do izbijanja Prvog svjetskog rata „važno... na umu imati razinu odgovornosti“ sudionika u tim događajima. ${ }^{7}$

U tom smislu cilj ovog članka je istražiti i ocijeniti stupanj odgovornosti službenih vlasti Kraljevine Srbije i ulogu revolucionarno-terorističke organizacije „Ujedinjenje ili smrt“, poznatije pod imenom „Crna ruka“ (u nastavku „Crna ruka“), u Sarajevskom atentatu i izbijanju Prvog svjetskog rata. Pri tome je važno, u mjeri u kojoj to dopušta dosegnuta razina povijesnih spoznaja i podatci iz raspoloživih tiskanih izvora, istražiti situaciju iza kulisa beogradske politike i beogradske obavještajne mreže koja se preko Drine protezala u Bosnu i Hercegovinu. Zato je potrebno odgovoriti na sljedeća istraživačka pitanja:

3 Mile Bjelajac, Novi (stari) zapleti oko uzroka Prvog svetskog rata pred obeležavanje 100. godišnjice, Tokovi istorije, svezak br. 1, 2013., 15, 39.

4 Mannfried Rauchensteiner, The First World War and the end of the Habsburg Monarchy, Wien, Koln, Weimar, 2014., 102.

5 Jay Winter and Antonie Prost, The Great War in History, Cambridge University Press, Cambridge, 2005., $34-57,192-212$.

6 Cristopher Clark, The Sleepwalkers. How Europe went to war in 1914?, London, 2012., XXVI XXVIII.

7 Sean Mcmeekin, July 1914. Countdown to war, New York, 2013., 342, 343. 
Kako su unutrašnje političke okolnosti u Kraljevini Srbiji utjecale na držanje službenih beogradskih vlasti prema sarajevskom atentatu? U kojoj mjeri postojanje beogradske obavještajne mreže u Bosni i Hercegovini službene vlasti Kraljevine Srbije čini odgovornima za Sarajevski atentat i kasnije zaplete koji su doveli do izbijanja Prvog svjetskog rata? Što motivi sarajevskih atentatora, njihovih beogradskih pomagača, ali i Nikole Pašića i njegove vlade, govore o umiješanosti službene politike Kraljevine Srbije u Sarajevski atentat? Što držanje beogradske vlade u razdoblju od Sarajevskog atentata 28. lipnja 1914. do isteka austrougarskog ultimatuma 25. srpnja 1914. govori o ulozi Kraljevine Srbije u Sarajevskom atentatu i stvaranju krize koja je izazvala Prvi svjetski rat?

Odgovori na ova pitanja trebali bi, kako je to izrazio Christopher Clark, „iscrtati liniju najveće moguće vjerojatnosti“" ${ }^{\text {“ }} \mathrm{kad}$ je u pitanju razina odgovornosti Kraljevine Srbije. U tom smislu članak je strukturiran na sljedeći način. Nakon kronološkog pregleda evolucije dosadašnjih spoznaja i kontroverzi koji je sačinjen po modelu koji je Annika Mombauer iskoristila za pisanje svog pregleda spoznaja o kontroverzama oko uzroka izbijanja Prvog svjetskog rata9 slijedi sedam poglavlja koja su fokusirana na političku i obavještajnu ulogu službenog Beograda u razvoju događaja koji su doveli do Sarajevskog atentata i diplomatskih zapleta koji su u konačnici rezultirali izbijanjem Prvog svjetskog rata. Nakon svega, u Zaključku, iznesena je ocjena odgovornosti Kraljevine Srbije.

U kronološkom smislu, članak će obuhvatiti razdoblje od nasilnog beogradskog prevrata u lipnju (po julijanskom kalendaru u svibnju) 1903. do neuspjelog pokušaja beogradske vlade da 25. srpnja 1914. diplomatski sredstvima zaobiđe austrougarski ultimatum uručen dva dana ranije.

\section{EVALUACIJA DOSADAŠNJIH SPOZNAJA I KONTROVERZI}

Kao što je već spomenuto, historiografske kontroverze oko odgovornosti Kraljevine Srbije za Sarajevski atentat i kasniji razvoj događaja koji je doveo do izbijanja Prvog svjetskog rata nisu nikakva novost. Tako je još 1926. R. W. SeatonWatson u svojoj knjizi o Sarajevskom atentatu i uzrocima Prvog svjetskog rata sasvim odbacio bilo kakvu odgovornost službenog Beograda, ističući da nakon Balkanskih ratova i tek okončane unutrašnje krize Srbiji u lipnju i srpnju 1914. „komplikacije spolja nisu bile nipošto dobrodošle“. Otud i njegova tvrdnja da 2002. 
je „sasvim... neverovatno, upravo groteskno, da bi vlada izabrala baš početak... izborne borbe kao čas zgodan da učestvuje u zaveri koja ide za ubijstvom na tuđem tlu, te koja bi lako mogla da dovede do rata“. ${ }^{10}$

Nasuprot njemu, američki povjesničar Sidney Bradshaw Fay je u svojoj klasičnoj studiji o uzrocima Prvog svjetskog rata istaknuo da su planovi za Sarajevski atentat dugo prije samog čina u Beogradu bili javna tajna zbog čega je, smatra Fay, beogradska vlada ,trebala smjesta obavijestiti austrougarske vlasti“, a ne nastojati „prikriti svaki trag... u nadi da austrougarska vlada neće biti ustrajna u otkrivanju njihove umiješanosti “. ${ }^{11}$

Drugi američki povjesničar, Bernadotte E. Schmitt, 1930. u svojoj detaljnoj monografiji o uzrocima Prvog svjetskog rata ističe da je „poteškoće u kojima se našao Pašić, lako... razumjeti, ali ako je imao spoznaja o zavjeri, pametnije bi postupio da je informacije prenio austrougarskoj vladi na nedvosmislen način“. Pašićevo uskraćivanje informacija autor smatra „zanemarivanjem dužnosti“ koje se „teško može opravdati““. ${ }^{12}$ Isto misli i Joachim Remak po kojem je Kraljevina Srbija imala „ogroman dio odgovornosti u izbijanju Prvog svjetskog rata“ jer „vlada u Beogradu nije poduzela nikakve mjere da spriječi atentat o kojem je imala prethodna saznanja“. Sam atentat, smatra Remak, isplanirala je „Crna ruka“, odnosno njezin vođa Dragutin Dimitrijević-Apis, koji je, kao i Nikola Pašić, bio nadahnut velikosrpskim idealima. ${ }^{13}$

Nasuprot svemu ovomu Vladimir Dedijer, u svojoj dvotomnoj monografiji o Sarajevskom atentatu, tvrdi da je Nikola Pašić, čim je početkom lipnja 1914. dobio informacije o tome da se priprema atentat na Franju Ferdinanda u Sarajevu, naredio srbijanskim civilnim vlastima da provedu istragu te je preko vojnih vlasti zatražio istragu o djelatnosti šefa srpske vojno-obavještajne službe i vladi u Beču uputio neizravno, i zbog toga kasnije osporavano, upozorenje. Prema Dedijeru, „tvrditi da je sarajevski atentat bio ili osnovni ili neposredni uzrok rata 1914. 1918., predstavljalo bi pretjerivanje. Pod drugim, normalnijim, međunarodnim okolnostima taj događaj ne bi mogao da izazove tako značajne posledice. ${ }^{\text {"14 }}$

$S$ tim u vezi poznati beogradski povjesničar Andrej Mitrović smatra da je vladi u Beču, zbog snažne potpore Njemačke, najvažnije bilo Sarajevski atentat iskoristiti kako bi se mogao „konstruisati rat sa Srbijom“. Mitrović ističe da nisu pronađeni podatci koji bi nedvojbeno upućivali na krivnju službenih vlasti u

10 Robert W. Seaton-Watson, Sarajevo. Studija o uzrocima svetskog rata, Zagreb, 1926., 87, 88.

11 S. B. FAY, The Origins of the World War, volume II, 57, 63.

12 Bernadotte E. Schmit t, The Coming of the War 1914, volume I, New York, London, 1930., 246.

13 Joachim Remak, The Third Balkan War. Origins reconsidered, The Journal of Modern History, svezak 43, br. 3, 1971., 364; J. REMAK, Sarajevo. Story of Political Murder, New York, 1959., 71 - 77.

14 Vladimir DediJe R, Sarajevo 1914, knjiga II, Beograd, 1978., 106 - 118, 278. 
Beogradu jer je, prema njegovu mišljenju, atentat „organizovala i izvela grupa nacionalnih revolucionara vođena svojim ubeđenjima" kojima su pomogli neki pripadnici „Narodne odbrane“ iz Srbije. ${ }^{15}$

Nasuprot Dedijeru i Mitroviću, američka povjesničarka Barbara Jelavich smatra da je u predvečerje Sarajevskog atentata, a nakon dvaju uspješnih Balkanskih ratova, beogradska politika dugoročno bila usmjerena prema stvaranju Velike Srbije i da je „na proljeće i ljeto 1914. ... bila suočena sa unutrašnjom krizom čija je najvažnija sastavnica bila pitanje sposobnosti vlade da nadzire vojsku“, a posebno „Crnu ruku“ koju je predvodio šef obavještajnog odjela glavnog stožera srbijanske vojske Dragutin Dimitrijević Apis. Jelavich smatra da je vlada u Beogradu prije atentata na "neizravan način“ upozorila bečku vladu, ali da nakon atentata nije "provela otvorenu i službenu istragu“. ${ }^{16}$

Slično kao i Jelavich, David MacKenzie u svojoj klasičnoj biografiji Dragutina Dimitrijevića Apisa ističe da je predsjednik vlade Kraljevine Srbije Nikola Pašić već početkom 1914. bio svjestan da „veze pukovnika Apisa s revolucionarnim bosanskim učenicima mogu ugroziti Srbiju“, odnosno da mogu dovesti do rata s Austro-Ugarskom. ${ }^{17}$

$\mathrm{Na}$ tom tragu Jack S. Levy smatra da je Srbija 1914. bila sklona očuvanju mira i da je bila spremna na ustupke Austro-Ugarskoj, ali samo do određene granice. U slučaju da ta granica bude pređena, „Srbija je davala prednost kontinentalnom ratu“ u kojem je očekivala potporu Rusije, zbog čega Levy smatra da je u historiografiji uloga Kraljevine Srbije „u širenju rata zanemarena“. U tom smislu i David Stevenson smatra da je „istraga kroz zamršenu povijest atentata potvrdila da srbijanske vlasti moraju snositi dosta krivice“ jer su atentatorima „srbijanski dužnosnici i vojni časnici dali bombe i revolvere u Beogradu i pomogli im da prijeđu granicu“". ${ }^{18}$

Slično Stevensonu i Samuel R. Williamson smatra da vlada Kraljevine Srbije nije bila spremna surađivati $s$ austrougarskim vlastima oko istrage poslije sarajevskog atentata, iako je taj atentat režirala „Crna ruka“, odnosno „skupina utjecajnih srbijanskih vojnih i političkih ličnosti, zakletih pristalica nasilnog rješavanja južnoslavenskog problema“. ${ }^{19}$

15 Andrej Mitrović, Prodor na Balkan. Srbija u planovima Austro-Ugarske i Njemačke 1908.-1918., Beograd, 1981., 21, 31.

16 Barbara Jelavich, History of the Balkans. Twentieth Century, volume II, Cambridge, New York, 1983., $109-112$.

17 David Mackenzie, Apis: Congenial Conspirator, New York, 1989., 124.

18 Jack S. Levy, Preferences, Constraints, and Choices in July 1914, International Security svezak 15, br. 3. 1990.-91., 156, 157; David STEvenson, The Outbreak of the First World War, New York, 1997., 3.

19 S. R. Williamson Jr., The Origins of World War I, 795, 804, 812. 
U najnovije vrijeme, odnosno u XXI. stoljeću, mnogi su autori detaljnije sagledali situaciju iza kulisa službenog Beograda. Tako Hew Strachan 2001. u prvom dijelu svoje voluminozne povijesti Prvog svjetskog rata smatra da se predsjednik srbijanske vlade Nikola Pašić, zbog vlastite političke slabosti, ustručavao vladi u Beču pružiti potpune informacije o pozadini sarajevskog atentata u koji su umiješani i državljani Srbije zbog čega „umiješanost vlade Srbije ostaje sporna i prijeporna točka“" ${ }^{20}$

Slično Strachanu, Richard C. Hall, koji inače negira odgovornost Srbije, smatra da su Nikola Pašić i neki članovi njegove vlade od početka lipnja 1914. bili svjesni da „Crna ruka" priprema atentat u Sarajevu, ali da je istraga pokrenuta u Beogradu ostala bez rezultata zbog otpora vojske, ali i zbog Pašićeva straha da ne razotkrije beogradsku obavještajnu mrežu u Bosni i Hercegovini. ${ }^{21}$

Nasuprot njima, David Fromkin ističe da je Kraljevina Srbija ne samo skrivala nego i poticala terorističku djelatnost protiv Austro-Ugarske. Zbog toga on austrougarski ultimatum od 23. srpnja 1914. smatra opravdanim. Fromkin uz to, povlačeći analogiju s onodobnim sukobom SAD i Meksika, ističe: „Ako je vlada nemoćna provesti zakon unutar svoga teritorija, ako ne može spriječiti upotrebu svog teritorija za nanošenje štete drugoj zemlji, onda ona gubi pravo da se njena suverenost poštuje“.22

Frank C. Zagare smatra da je Sarajevski atentat bio teroristički čin koji je, „iako nije bio sponzoriran od strane državnih vlasti, ipak ... bio potaknut od strane pojedinaca u obavještajnoj zajednici“ Kraljevine Srbije. ${ }^{23}$

Sean McMeekin smatra da danas postoji „temeljna suglasnost da je Srbija umiješana u sarajevski atentat" jer, usprkos brojnim nepoznanicama oko toga što su političke vođe u Beogradu zaista znali o planovima organizacije „Ujedinjenje i smrt“, „u tadašnjem malom Beogradu...zavjera nije mogla biti tajna“. ${ }^{24}$

20 Hew Strachan, The First World War, volume I, New York, 2001., 66, 67, 68.

21 Skidajući izravnu odgovornost s leđa Kraljevine Srbije, Hall ističe kako sarajevski atentat nije potakao rat, nego je to učinila upotreba ovog događaja od strane Austro-Ugarske, pri čemu Hall ključnim događajem smatra austrougarski ultimatum Srbiji od 23. srpnja 1914. R. C. HALL, Serbia, The Origins of World War I, ur. Richard F. Hamilton, Holger. H. Helwig, Cambridge, New York, 2003., $107-111$.

22 David From Kin, Europe's Last Summer. Who started Great War in 1914., New York, 2004., 265.

23 Frank. C. Zagare, The Games of July, Michigan, 2011., 189.

24 McMeekin smatra „da su visoki srbijanski dužnosnici bili umiješani u zločin“ koji Nikola Pašić nije ni pokušao spriječiti niti je, kasnije, proveo pravu istragu o okolnostima u kojima se atentat dogodio. Ipak, smatra McMeekin, „Gavrilo Princip i njegovi suzavjerenici snose najveću odgovornost za izazovanje srpanjske krize činom ubojstva nadvojvode Franje Ferdinanda“, s tim da „ni Princip ni Crna ruka nisu namjeravali izazvati svjetski rat...". Sean MCMEE KIn, The Russian Origins of the First World War, Cambridge, London, 2011., 42 - 47; S. MCMEekin , July 1914. Countdown to war, 343. 
Cristopher Clark ističe da je danas mnogo jasniji „balkanski kontekst početka rata“ i da je „Srbija je jedna od slijepih točaka“u historiografskim raspravama zbog čega „stavljanje Sarajeva i Balkana nazad, u središte priče, ne znači demoniziranje Srba ili njihovih državnika, niti nas oslobađa od obveze da razumijemo vanjske i unutrašnje sile koje su djelovale na one srbijanske političare, časnike i aktiviste čije je ponašanje i odluke koje su donijeli, doprinijelo određivanju posljedica pucnjeva u Sarajevu“. ${ }^{25}$

Slično Clarku, Margareth MacMillan smatra da „Srbija nije bila u stanju, i u najvećoj mjeri nije bila ni voljna, obuzdati različite nacionalističke organizacije koje su agitirale među južnim Slavenima u Austro-Ugarskoj“ i koje su novac i oružje dobivale od srpske vojske. Među njima ona ističe „Mladu Bosnu“, čiji su članovi bili Gavrilo Princip i njegovi suradnici u Sarajevskom atentatu. ${ }^{26}$

Sličan stav donosi i Olga Popović-Obradović u svojoj detaljnoj analizi političkog sustava Kraljevine Srbije početkom XX. stoljeća. „Crnu ruku“, ali i beogradski vojni vrh općenito, ona smatra „izvan-ustavnim činiocima“ koje Nikola Pašić, iako je u zakulisnoj borbi za vlast pobijedio, nije smogao snage u cijelosti nadzirati. ${ }^{27}$

Nasuprot svemu ovomu, Dušan T. Bataković smatra da je austrougarska aneksija Bosne i Hercegovine 1908., a ne držanje Srbije u lipnju i srpnju 1914., pravi povod za izbijanje Prvog svjetskog rata. Ovo tim više što je, prema Batakoviću, beogradska vlada u slučaju Sarajevskog atentata napravila sve što je mogla da ga spriječi i da se izbjegne širi sukob. ${ }^{28}$

Slično Batakoviću, Mile Bjelajac smatra da vlada Kraljevine Srbije 1914. nije bila upoznata s planovima „Crne ruke“ te da umiješanost te organizacije u Sarajevski atentat, zbog nedostatka izvornih dokumenata, nije nepobitno dokazana. ${ }^{29}$

25 „Ubojstvo u Sarajevu do sada se tretiralo samo kao pretekst, koji je imao ograničeni utjecaj na izbijanje rata“, ističe Clark te smatra da danas, u promijenjenim okolnostima na početku 21. stoljeća, neke stvari vidimo jasnije nego naši pretci prije stotinu godina, posebno zbog toga što je, kako kaže, „od Srebrenice i opsade Sarajeva teško misliti o Srbiji kao o žrtvi politike velikih sila i može je se gledati kao silu koja ima vlastite ciljeve i snagu“. C. CLARK, The Sleepwalkers, XXVI - XXVIII.

26 Margareth MACMILlan, War that ended the peace, London, 2013., 465, 514.

27 Olga Popović-Obradović, The Parliamentary system in Serbia 1903. - 1914., Beograd, 2013., 586 - 588.

28 Dušan T. Bataković, The Salonica trial 1917. Black Hand vs Democrarcy, The Salonica Theatre of operation and the outcome of Great War, Institute for Balkan studies, svezak 277, 2005., 281; D. T. BAta ković, Storm over Serbia. The Rivalry between Civil and Military authorities (1911. - 1914.), Balcanica, svezak 44, 2013., 350.

29 Bjelajac ističe da ,istoričari ne oskudevaju u teorijama“ koje su, smatra, rezultat propagandnih potreba Njemačke, Austro-Ugarske, ali i osobnih animoziteta koje pojedini autori osjećaju prema Srbiji. Bjelajac ide toliko daleko da u svemu vidi utjecaj „srbofobije“. M. BJELAJAC, Novi (stari) zapleti oko uzroka Prvog svetskog rata, 19 - 26, 39. 
Nasuprot njima, austrijski povjesničar Manfried Rauchensteiner smatra da oni koji su u Srbiji bili na vlasti 1914. „nisu bili voljni priznati da je, doslovno pred očima vlade, stvorena mreža koja je promicala jasan cilj uništenja AustroUgarske“, čak ni onda kad je bilo jasno da su pojedinci iz te mreže organizirali i izvršili sarajevski atentat. ${ }^{30}$

Ipak, prema mišljenju Gordona Martela, „može se pokazati nemogućim dokazati umiješanost srbijanskih vlasti“ u zavjeru za izvršenje sarajevskog atentata, iako je ta „zavjera bila dobro organizirana i iako se njeni tragovi mogu pratiti do Beograda“ gdje je cilj tamošnje vlade nesumnjivo bio „sve južne Slavene ujediniti pod svojom zastavom" . $^{31}$

\section{POLITIČKI KONTEKST KRALJEVINE SRBIJE POČETKOM XX. STOLJEĆA}

U kronološkom smislu ishodišna točka ovog istraživanja je beogradski prevrat iz lipnja 1903. (po julijanskom kalendaru nazvan „Majski prevrat“), kojim je skupina časnika-zavjerenika ubojstvom uklonila dinastiju Obrenovića i na prijestolje dovela vladarsku obitelj Karađorđevića. Ovaj je prevrat donio promjene u unutrašnjoj politici jer je uveden sustav parlamentarne monarhije, dok se u vanjskoj politici Srbija, nakon dva desetljeća pod okriljem AustroUgarske, okrenula Rusiji i Francuskoj. Iako su zavjerenici vlast predali Narodnoj skupštini i iako su u javnosti slavljeni kao obnovitelji demokracije, oni su i dalje imali vrlo velik politički utjecaj. Čak je i kralj, koji je zavjerenicima dugovao prijestolje, morao voditi računa o njihovim željama koje su oni često ostvarivali prijetnjama i nasiljem. To je, posebno nakon aneksijske krize 1908. i 1909., u Srbiji dovelo do porasta militarizma i nastanka ratne psihoze koja se, prema riječima Olge Popović-Obradović, očitovala kao vrlo rašireno uvjerenje da Srbija mora imati veliku i spremnu vojsku koja je, gradeći veze s relevantnim političkim snagama u zemlji, težila imati što veći politički utjecaj. ${ }^{32}$

U ovakvoj situaciji nakon što je, preširoko tumačeći načelni sporazum $s$ Rusijom, Austro-Ugarska 1908. anektirala Bosnu i Hercegovinu, kojom je po međunarodnom mandatu upravljala prethodna tri desetljeća, u Srbiji je došlo do erupcije ratnog raspoloženja što je rezultiralo osnivanjem „Narodne obrane“, masovne organizacije pod okriljem vlade koja je isprva imala otvoreno vojno- 
obavještajnu zadaću. Nakon što je vlada u Beogradu 1909. pod pritiskom Beča priznala aneksiju, „Narodna obrana“ je fiktivno transformirana u kulturnoprosvjetno udruženje koje je u Bosni i Hercegovini nastavilo stvarati mrežu agenata koji su se bavili obavještajnom i propagandnom djelatnošću, ali i novačenjem ovdašnjih mladića u četničke postrojbe u Srbiji.

Dvije godine kasnije, 1911., bivši oficiri-zavjerenici osnovali su organizaciju „Crna ruka“, u kojoj su okupili između petstotinjak i dvije tisuće članova i čiji je cilj, prema statutu i pravilniku organizacije, bio „ujedinjenje srpstva“ revolucionarnim putem, odnosno borbom „svim sredstvima protiv sviju neprijatelja ove ideje“. Iako je organizacija imala svoje vodstvo pod nazivom Vrhovna centralna uprava, glavnu je riječ vodio Dragutin Dimitrijević Apis, koji je od siječnja 1913. bio šef beogradske vojno-obavještajne službe, zbog čega je pod svojim nadzorom imao i obavještajnu mrežu „Narodne odbrane“ kojom se koristila i „Crna ruka“. Suprotno ustaljenim predodžbama, „Crna ruka“ nije bila tajna organizacija u punom smislu te riječi jer je svoja stajališta iznosila javno, kroz glasilo Pijemont, a njezino postojanje bilo je poznato ne samo beogradskoj vladi i beogradskom tisku nego i stranim diplomatima u Srbiji. Ipak, statut i poslovnik ove organizacije bili su tajna, ne samo za javnost nego i za obične članove, jer je vodstvo „Crne ruke“ namjeravalo iz sjene nadzirati beogradsku vladu. Zbog toga se „Crnu ruku“i A pisa smatralo opasnim prevratnicima.

Uspjeh u Balkanskim ratovima 1912. i 1913., osim što je skoro udvostručio teritorij Srbije, dodatno je militarizirao tadašnje srbijansko društvo i pred vladu u Beogradu jasnije stavio mogućnost aneksije austrougarskih područja koja su smatrana srpskim ili mogućnost realizacije jugoslavenskog političkog programa pod egidom Velike Srbije. Ipak, Srbija je na osvojenim područjima na jugu imala pune ruke posla s bugarskim gerilcima u Makedoniji i albanskim gerilcima na Kosovu zbog čega je glavnina njezine vojske, znatno istrošene u Balkanskim ratovima, bila smještena na ovim područjima, ostavljajući sjevernu granicu prema Austro-Ugarskoj slabo branjenu. Zbog toga, ali i zbog sukoba vojske i civilnih vlasti oko nadležnosti u novim pokrajinama, predsjednik vlade Nikola Pašić osjećao je da je Srbija ranjiva, pa je smatrao da pod svaku cijenu treba izbjeći rat s Austro-Ugarskom.

U ovakvim okolnostima, u svibnju i lipnju 1914., kulminirao je sukob između Apisa, koji je iza sebe imao vojsku, ali i ujedinjenu skupštinsku oporbu, i Pašića, kojem je otvorena potpora ruskog veleposlanika u Beogradu Nikolasa Hartwiga pomogla da opstane na vlasti. No, ova medalja ima i drugu stranu. Naime, Apis je sa skupinom pripadnika „Crne ruke“namjeravao preuzeti nadzor nad novoosvojenim područjima, a zatim izvesti državni udar sličan onome iz 1903. Od toga ipak nije 
bilo ništa jer je Pašić preko svojih agenata u „Crnoj ruci“ bio obaviješten o ovim akcijama, pa su zavjerenici u zadnji čas odustali od svoga plana. ${ }^{33}$

Iza svega je, prema riječima povjesničara Radovana M. Draškovića, stajala činjenica da je Pašićeva vlada imala „svoje uši i oči u neposrednoj blizini Apisovoj i tačno je znala za sve pripreme" te je pripremila opasni protuplan. U tom smislu ilustrativno je upozorenje koje je Apisu uputio monah, kasniji episkop pravoslavne crkve dr. Nikola Velimirović: „Dragi prijatelju, ja se bojim za vas, i u slučaju kakvog pokušaja nasilnim merama da ovom pitanju date epilog, zasede koje su postavljene pobiće i vas i vaše društvo. Uzmite to na znanje i prema tome se upravljajte, a ja vas molim da budete razumni i ne činite ništa što bi vas moglo stajati glave." ${ }^{34}$

Iako Drašković kao izvor podataka navodi kasnije razgovore s Dušanom Stefanovićem, tadašnjim ministrom obrane, i bivšim ministrom Vojom Janjićem, što u izvjesnoj mjeri u pitanje dovodi vjerodostojnost čitave priče, ostaje činjenica da je u nasilnom ozračju tadašnje srbijanske politike ovakav scenarij prilično vjerojatan, što potvrđuju i novija istraživanja povjesničara Vase Kazimirovića. ${ }^{35}$

Da je tome tako svjedoče primjeri koji pokazuju kako su pripadnici „Crne ruke“ prema političkim protivnicima redovito bili nasilni. Tako je 1911.jedan od stožernih časnika srbijanske vojske i član „Crne ruke“ došao u vladu, lupio nogom o pod i prijetećim posezanjem za sablju tadašnjem ministru financija Stojanu Protiću dao do znanja da se mora prestati odupirati trošenju proračunskog novca na djelatnost pograničnih časnika koji su za račun „Crne ruke“ vršili obavještajnu djelatnost u Makedoniji i Bosni i Hercegovini i koji su kasnije imali važnu ulogu u sarajevskom atentatu. Osim toga, Protić je, kao poznati protivnik „Crne ruke“ doživio i to da ga je pred njegovim vlastitim domom sačekao utjecajni aktivist „Crne ruke“ Vojin Tankosić i prijeteći mu poručio da se „ne igra vatrom jer će, inače jednog dana odleteti u vazduh zajedno sa kućom i celom familijom“. Prijetnjama je 1912. bio izložen premijer i ministar vanjskih poslova Milovan Milovanović kojemu je usred bijela dana u fijaker prijeteći uskočio Tankosić,

33 R. M. Draš Ković, Pretorijanske težnje u Srbiji, Beograd, 2006., 5 - 57, 185, 186; D. T. BATAKović, Storm over Serbia, 310, 316, 324, 326; B. Jelavich, History of the Balkans, 106 - 111; Vasa Kazimirović, Crna ruka, Kragujevac, 1997., 317 - 323, 378 - 380; D. Mackenzie, Apis: The Congenial Conspirator, 72, 108 - 122, 135, 136; O. Popović-OвRAdović, The Parliamentary system, 164, 173, 340, 585 - 588; H. Strachan, The First World War, 64 - 67; M. Ž. Živković, Pukovnik Apis. Solunski proces hiljadu devetsto sedamnaeste, Beograd, 1955., 669 - 679; M. BJELAJAC, Novi (stari) zapleti, 22, 23, 55; C. ClARK, The Sleepwalkers, 43, 44; R. C. HALL, Serbia, 104, 105; Vasa Kazimirović, Crna ruka, Kragujevac, 1997., 317, 323, 378 - 380.

34 R. M. Draš Ković, Pretorijanske težnje, 185, 186.

35 R. M. Draš Ković, Pretorijanske težnje, 185, 186; V. Kazimirović, Crna ruka, 597. 
tražeći aktivniji odnos vlade prema stvaranju balkanskog saveza za nadolazeći rat s Osmanskim Carstvom, zbog čega je Milovanović vrlo brzo našao zajednički jezik s „Crnom rukom“ te je kasnije čak i nastojao zataškati njihovu zavjereničku djelatnost o kojoj je pisao britanski tisak. ${ }^{36}$

Ovakvo stanje stvari je, prema riječima Joachima Remaka, omogućavalo beogradskoj vladi da ima uvid u djelatnost „Crne ruke“ koja je u prvo vrijeme otvoreno surađivala s pojedinim ministrima zbog čega valja vjerovati da je barem dio ovih komunikacijskih kanala ostao otvoren i kasnije te da su Pašić i njegovi ministri 1914. u izvjesnoj mjeri bili upoznati s planovima za sarajevski atentat. $\mathrm{U}$ prilog tome Remak ističe u literaturi često navođenu tezu, o kojoj opširnije u nastavku, da je operativac "Crne ruke“ i jedan od neposrednih organizatora sarajevskog atentata Milan Ciganović „vrlo vjerojatno bio Pašićev osobni agent“.37

Ovdje na umu valja imati i činjenicu da je Apisa i Pašića povezivao zajednički strateški cilj, stvaranje Velike Srbije na osnovu Načertanija Ilije Garašanina, što znači da je uzrok njihova sukoba bio na taktičkoj razini, odnosno oko pitanja trenutka i načina ostvarenja zajedničkog cilja. Zato ne čudi da su tijekom Balkanskih ratova sukobljene strane svoje razmirice stavile na stranu i da je „Crna ruka“ djelovala kao obavještajna ruka vanjske politike beogradske vlade. ${ }^{38}$

Ipak, u proljeće i ljeto 1914. Pašić je, nasuprot bezuvjetnoj ratobornosti „Crne ruke“, zbog iscrpljenosti zemlje i vrlo lošeg stanja vojske bio sklon izbjeći, ili barem odgoditi, sukob s Austro-Ugarskom. ${ }^{39}$ Prema podatcima u arhivskoj ostavštini Svetozara Pribičevića, u vrhovima vlade u Beogradu tada se vjerovalo da će u slučaju napada Austro-Ugarske na Srbiju izbiti svjetski rat. Također, računalo se da je Srbiji potrebno 3 - 10 godina mira, odnosno do trenutka kad Antanta 1917. dosegne vrhunac svoje vojne pripravnosti i dok Srbija vojno i politički ne asimilira područja osvojena u Balkanskim ratovima. ${ }^{40}$ Ovo držanje beogradske

36 Milorad Belić, Vojvoda Tankosić, Valjevo, 2005., 33, 45; Milan RA KIć, Konzulska pisma 1905-1911, Beograd, 1985., 327; D. T. Bataković, Storm over Serbia, 335; R. M. Draš ković, Pretorijanske težnje, 146, 147; V. KAzIMIRović, Crna ruka, 513.

37 J. REMAK, Sarajevo, 49, 71.

38 R. C. Hall, Serbia, 93, 94; D. Mackenzie, Apis: Congenial Conspirator, 69, 70.

39 Prema raspoloživim podatcima Srbiju su Balkanski ratovi stajali 370 milijuna dinara, tri godišnja državna proračuna, što je povećalo proračunski deficit ionako prezadužene države. Dodatni teret predstavljao je kredit od oko 120 milijuna dinara namijenjen opremanju vojske iscrpljene u Balkanskim ratovima, koji je beogradska Narodna skupština nevoljko izglasovala u lipnju 1914., deset dana prije sarajevskog atentata. G. MARTel, The Month that changed the World, 84; R. C. Hall, Serbia, 106.

40 Naime, prema riječima Ljubomira Jovanovića koji je u tadašnjoj Pašićevoj vladi bio ministar prosvjete, Srbiji je trebalo vremena za popunu vojske oslabljene gubitcima u Balkanskim ratovima, da nabavi novo oružje te da napravi strateške željeznice do novoosvojenih krajeva, što je trebalo ubrzati njihovu asimilaciju. Bogdan KRIZMAN, Hrvatska u prvom svjetskom ratu, Zagreb, 1989., 45, 47. 
vlade jezgrovito je opisao Mile Bjelajac tvrdnjom da je "nedvosmisleno je da je Srbija bacala pogled na oslobođenje i ujedinjenje sa braćom u Bosni, ali do pogodne međunarodne konjukture je bilo daleko". ${ }^{41}$ Sve u svemu, Pašić i njegovi suradnici nisu, kako se to često tvrdi, bili bez saznanja o sarajevskom atentatu i njegovoj pozadini. Naprotiv.

\section{BEOGRADSKA OBAVJEŠTAJNA MREŽA U BOSNI I HERCEGOVINI}

Ipak, Mile Bjelajac negira umiješanosti beogradske vlade u sarajevski atentat, tvrdeći da je „Mlada Bosna“ bila autohtoni pokret i da je „u njenom krilu rođena ...ideja za atentat kakav se ranije pripremao na cara i druge velikodostojnike. Potreba Srbije za predahom i oporavkom te dugim periodom mira nije se shvatala. “ ${ }^{42}$ Bjelajac pri tome ne mimoilazi postojanje beogradske obavještajne mreže u Bosni i Hercegovini koju je vlada Kraljevine Srbije, neizravno, uglavnom preko „Narodne odbrane“, financirala, ekipirala i nadzirala i o kojoj je Nikola Pašić imao jasnu predodžbu. Stoga ni sarajevski atentatori, ali ni „Crna ruka“ nisu bili potpuno neovisni akteri jer je linija zapovijedanja sezala od obavještajne mreže u Bosni i Hercegovini, u koju su bili uključeni i budući sarajevski atentatori, preko Drine, do službenih vlasti u Beogradu.

Da je tome tako svjedoče izvorni podatci koje je objavio sudac istražitelj nakon Sarajevskog atentata 1914. Leo Pfeffer. Prema tim podatcima austrougarske su vlasti tijekom ratnih operacija u Srbiji u jesen 1914. zaplijenile mnoge povjerljive dokumente koji svjedoče o djelatnosti beogradske obavještajne mreže pri čemu se posebno izdvaja dnevnik pograničnog časnika u Loznici i povjerenika „Crne ruke“, Koste Todorovića, kroz čije je ruke prolazio novac za odlazak mladića iz Bosne i Hercegovine na četničku obuku u Srbiju, koji je imao podatke o beogradskim povjerenicima na terenu i koji je kasnije bio jedna od ključnih osoba u prebacivanju sarajevskih atentatora preko Drine. ${ }^{43}$ Posebno je zanimljivo što Pfeffer navodi da su postojale dvije vrste povjerenika, organizirani i neorganizirani, pri čemu „organizirani su bili zaprisegnuti, te im je bilo zaprijećeno smrću u slučaju da odadu organizaciju“. Ovo jasno ukazuje da je bila riječ o članovima „Crne ruke“ koji su polagali sljedeću prisegu: „Ja ...

41 M. BJelajac, Novi (stari) zapleti, 22.

42 M. BJelajac, Novi (stari) zapleti, 20.

43 L. PFEFFER, Istraga o sarajevskom atentatu, 17 - 22; Vojislav BogIĆEvić, Sarajevski atentat. Izvorne stenografske bilješke sa glavne rasprave protiv Gavrila Principa i drugova, održane u Sarajevu 1914. g., Sarajevo, 1954., 319, 320, 341, 342. 
zaklinjem se suncem koje me greje, zemljom što me hrani, bogom, krvlju svojih otaca, čašću i životom da ću od ovog časa pa do smrti verno služiti zadatku ove organizacije.“" ${ }^{44}$ Opisujući pobliže ulogu ove beogradske obavještajne mreže u sarajevskom atentatu, Pfeffer ističe da je jasno „da su neke osobe, koje su pomagale atentatorima, bile u vezi s tim pograničnim oficirima" koji su, kako je to prethodno spomenuto, za potrebe „Crne ruke“ prikupljali obavještajne podatke. Riječ je bila o beogradskim povjerenicima u Bosni i Hercegovini koji su najčešće bili članovi „Narodne odbrane“ ili članovi srpskih sokolskih društava. ${ }^{45}$

Jedan od takvih je bio izvjesni Jovo Jagličić prema čijem je svjedočenju, pročitanom na sarajevskom procesu atentatorima u listopadu 1914., „Narodna odbrana" vršila obavještajnu djelatnost, ali je i pripremala diverzante koji su trebali djelovati u slučaju izbijanja rata Austro-Ugarske i Srbije. ${ }^{46}$ Drugi je bio Trifko Krstanović, koji je 1909. bio unovačen u mrežu „Narodne odbrane“ te je prošao četničku obuku koja je bila financirana proračunskim novcem Kraljevine Srbije. Nakon obuke koja je trajala tri mjeseca Krstanović je najprije bio kurir lokalnog čelnika „Narodne odbrane“ u Šapcu Bože Milanovića, nakon čega je, 1910., poslan u Bosnu i Hercegovinu kao povjerenik. ${ }^{47}$

Zato je Krstanović na sudskom procesu u Sarajevu u listopadu 1914. na upit sudca: "Je li ima Narodna odbrana veze sa generalštabom Srbije?" odgovorio: „Mislim da jeste.“ Ovdje je važno spomenuti da su istu obuku kao i Krstanović prošli i sarajevski atentatori Gavrilo Princip i Vladimir Gaćinović te kasniji povjerenik „Narodne odbrane“ u Sarajevu Danilo Ilić. Prema objavljenim austrougarskim dokumentima ovu je obuku 1909. prošao i Milan Ciganović, povjerenik "Crne ruke“ koji je pomogao sarajevskim atentatorima i koji je vjerojatno bio agent Nikole Pašića. ${ }^{48}$

Četnička obuka odvijala se 1908. i 1909. u mjestu Ćuprija, na krajnjem jugu tadašnje Srbije, te je obuhvaćala rukovanje dinamitom, bombama, brzometnom puškom i fizičke pripreme. Četnici su od beogradske vlade dobivali plaću koja

44 L. Pfeffer, Istraga o sarajevskom atentatu, 22; Tajna prevrtana organizacija. Izveštaj sa pretresa vojnog suda za oficire u Solunu, Solun, 1918., 361, 362.

45 L. PFEFFER, Istraga o sarajevskom atentatu, 100, 114, 115;

46 V. Bogićević, Sarajevski atentat, 306; Austro-Hungarian Red Book, Collected Diplomatic Documents Relating to the the Outbreak of the European War, London, 1915., 487 - 489.

47 Prema Pfefferovim riječima, u četnički logor su svakih dva tjedna dolazili članovi vodstva „Narodne odbrane“, ali i posebni činovnik Ministarstva financija Kraljevine Srbije koji je podmirivao troškove četničke obuke. Ovi podatci bili su poznati i vrhovima vlasti u Beču koje su ih, nakon uručenja ultimatuma Srbiji, proslijedile u London, Berlin, St. Petersburg, Rim, Pariz i Carigrad. L. Pfeffer, Istraga o sarajevskom atentatu, 118 - 120; Austro-Hungarian Red Book, 461, 462, 480 - 487.

48 V. Bogićević, Sarajevski atentat, 258 - 265, 285, 310; Austro-Hungarian Red Book, 470. 
se kretala od 10 do 80 dinara za obične vojnike i 150 dinara za časnike. $\mathrm{Za}$ razumijevanje obavještajne djelatnosti „Narodne odbrane“i injezine isprepletenosti s djelatnošću „Crne ruke“, karakteristično je da je četničko oružje i streljivo nakon obuke bilo uskladišteno u spremištima „Narodne odbrane“ u gradu Vranju. ${ }^{49}$

Konspirativni karakter beogradske obavještajne mreže u svom je svjedočenju na sarajevskom procesu u listopadu 1914. ukratko opisao i atentator Trifko Grabež. Suočen s dokumentiranim dokazima da „Narodna obrana“ nije bila tek obično kulturno-prosvjetno društvo, nego da je i programski bila usmjerena na rušenje Austro-Ugarske, Grabež je rekao da „po ovom štatutu izgleda da je uperena protiv Monarhije, ali drugi program koji su sastavili, izgleda da je čisto kulturan“. .50

Povezanost „Narodne odbrane“ s vrhovima vlasti u Beogradu najjasnije je izrazio sam Nikola Pašić koji je neposredno iza sarajevskog atentata, želeći izbjeći provociranje vlade $u$ Beču, ovoj organizaciji „zabranio...da ma išta radi u duhu nacionalne agitacije u Austro-Ugarskoj". ${ }^{51}$ Stoga ne čudi da je u najnovije vrijeme čak i Dušan T. Bataković, koji inače odbacuje bilo kakvu odgovornost Kraljevine Srbije za sarajevski atentat, konstatirao da je „Narodna odbrana“, pored propagande i obrazovne djelatnosti, bila organizacija čije se djelovanje od samog početka „svelo na održavanje mreže agenata koji su bili u stalnom dodiru i sa civilnom i sa vojnom obavještajnom službom u Beogradu“.52 O tome svjedoči i Mile Bjelajac koji, na osnovu podataka iz objavljene arhivske građe, ističe kako je Apis u jednom dopisu iz srpnja 1914. tražio nemiješanje policijskih vlasti, ali i „Narodne odbrane“ u njegovu obavještajnu djelatnost, što će reći i djelatnost „Crne ruke“. ${ }^{33}$

\section{„MLADA BOSNA“ I BEOGRADSKA OBAVJEŠTAJNA MREŽA}

U Apisovu obavještajnu mrežu bili su uvučeni i pripadnici „Mlade Bosne“, primjer čega je nesuđeni sarajevski atentator Vladimir Gaćinović koji je tijekom 1911. boravio u Beogradu, gdje je pristupio i „Narodnoj odbrani“ i „Crnoj ruci“ te je nakon povratka u rodnu Bosnu i Hercegovinu postao ovdašnji obavještajni povjerenik. ${ }^{54} \mathrm{O}$ povezanosti „Mlade Bosne“ s beogradskom obavještajnom mrežom svjedoči epizoda s početka 1914. kada je Vojislav Tankosić, da bi prikrio

49 M. BELIĆ, Komitski vojvoda Vojislav Tankosić, 29.

50 V. BogIĆEvić, Sarajevski atentat, 311.

51 Đorđe Đ. Stanković, Nikola Pašić, saveznici i stvaranje Jugoslavije, Nolit, Beograd, 1984., 29.

52 D. T. Bataković, Storm over Serbia, 324.

53 M. Bjelajac, Novi (stari) zapleti, 25.

54 V. Dedijer, Sarajevo 1914., 228, 229, 374, 382; V. BogićEvić, Sarajevski atentat, 35, 59. 
tragove djelatnosti „Crne ruke“ u Bosni i Hercegovini, sastanak s nekoliko mladobosanaca organizirao u Touloseu u Francuskoj. Iako se planovi koji su tamo bili iskovani nisu ostvarili, sam sastanak pokazuje da su mladobosanci bili uvučeni u Apisovu mrežu. Ovdje je važno naglasiti da je Tankosić bio odlučan „da se uradi nešto konkretno za srpsku stvar“, što ga je u očima budućih sarajevskih atentatora činilo pravom osobom od koje se može dobiti ohrabrenje, ali i konkretna pomoć za ostvarenje njihove zamisli. Ovo tim više što se on, vjerojatno još od 1911., bavio mišlju o organiziranju atentata na Franju Ferdinanda. ${ }^{55}$

Sagledavajući okolnosti koje su prethodile Sarajevskom atentatu, Dušan T. Bataković u najnovije je vrijeme ponovo aktualizirao upitnu tezu kako je zamisao o atentatu potekla isključivo iz redova „Mlade Bosne“ te da su Apis i Tankosić mlade atentatore ohrabrili i dali im logističku potporu, bez znanja vlade $u$ Beogradu, ali i uprave „Crne ruke“.56 Bataković je međutim mimoišao podatak koji je donio još Vladimir Dedijer, kako su sarajevski atentatori od „Crne ruke“, osim oružja i bombi, dobili i znatan novčani iznos koji se kretao od 130 do 1000 srpskih dinara, iza čega su, kao u prethodno spomenutom slučaju financiranja četničke obuke, vjerojatno stajale državne financije Kraljevine Srbije, a možda i financijska potpora iz Rusije ili novac koji je „Crna ruka“ nezakonito izvukla iz javnih fondova. ${ }^{57}$

Samuel R. Williamson zato, na osnovu opširnog pregleda znanstvenih spoznaja o ovom pitanju, smatra da je Apis otprije planirao ubojstvo Franje Ferdinanda te da je ,iskoristio nacionalizam mladih učenika i nemogućnost Pašićeve vlade da nadzire Crnu ruku“. ${ }^{58} \mathrm{U}$ prilog tome ide i stajalište Roberta

D. Mackenzie, Apis: Congenial Conspirator, 74,75; V. Dedijer, Sarajevo 1914., knj. I, 87; J. Rem A K, Sarajevo, 54, 55. Prema arhivskim podatcima koje donosi Milorad Belić, Tankosić je bio povezan i s tzv. revolucionarnom omladinom u Hrvatskoj te je čak bio sponzor atentata na komesara Slavka Cuvaja u Zagrebu. M. Belić, Komitski vojvoda Vojislav Tankosić, 31, 32, 50, 51.

56 Upitnost ove teze potvrđuje i sam Bataković navodeći da ona počiva na Apisovu pismenom priznanju na Solunskom procesu 1917., koje je dao u nadi da će tako spasiti vlastiti život, ali i na političkim računicama tadašnje srbijanske vlade u izbjeglištvu koja je time pripremala teren za mogući separatni mir s Austro-Ugarskom, ali se također htjela riješiti opasnog protivnika. D. T. Bata ković, The Salonica trial 1917. Black Hand vs. Democracy, 281, 282, 288.

57 V. Dedijer, Sarajevo 1914., knj. I, 382. Ruski vojni ataše u Beogradu pukovnik Artomanov je poslije Prvog svjetskog rata priznao da je „Crnu ruku“ snabdijevao novcem za njezinu obavještajnu djelatnost. David Fromkin kao mogući izvor financiranja „Crne ruke“ navodi zloupotrebu dijela od oko 4 milijuna franaka kojim je ruska vlada još od 1910. sponzorirala srpski časnički kor. Naime, u proljeće 1914. u javnost je dospjela afera s fondom „Oficirske zadruge“ koji je bio pod nadzorom "Crne ruke“ i koja je iz njega izvukla oko 700.000 dinara za financiranje svoje djelatnosti. C. Clark, The Sleepwalkers, 412; J. Rem A , Sarajevo, 57. D. From Kin, Europe's Last Summer, 130; V. Kazimirović, Crna ruka, 588, 589.

58 S. R. Williamson, The Origins of World War I, 804, 805. 
Okeyja koji je, nakon opširnog uvida u literaturu o „Mladoj Bosni“, ustvrdio da su Princip i mladobosanci bili socijalno marginalizirani pojedinci, zaneseni srpskom nacionalnom predajom, koji su, usprkos kulturološkoj, anarhističkoj i modernističkoj pobuni protiv starijih naraštaja, u izvjesnoj mjeri ipak bili oruđe srbijanske vojno-obavještajne službe. Iz ovakvog višeslojnog mentalnog sklopa vjerojatno je proisteklo i njihovo odbijanje da odustanu od atentata kada je to, sredinom lipnja 1914., vodstvo "Crne ruke“ od njih zatražilo. ${ }^{59}$

Ovakav razvoj događaja stoga je imao obilježje nepredviđenosti i iracionalnosti jer kao što vlada u Beogradu nije mogla nadzirati Apisa i njegovu djelatnost, tako on nije mogao nadzirati mlade atentatore. Zato je u nastavku važno ispitati motive koji su pokretali sarajevske atentatore i „Crnu ruku“, ali i vladajuću elitu u Beogradu.

\section{MOTIVI ZA ATENTAT}

U tom je smislu karakteristično suvremeno svjedočanstvo povjesničara, novinara i pravnika Slobodana Jovanovića koji je Apisa i članove „Crne ruke" smatrao nesebičnim patriotima, ali i opasnim fanaticima kojima je „patriotsko oduševljenje ugušilo svaku kritičnost“ pa su „kao mesečari postali neosetljivi za teškoće i opasnosti. Tražili su akciju što pre i po svaku cenu“. ${ }^{60}$ Ovo svjedočanstvo na vrlo slikovit način dočarava ratoborno i vrlo iracionalno ozračje kako unutar "Crne ruke“ i unutar beogradske obavještajne mreže u Bosni i Hecegovini, ali i unutar beogradske političke elite, pri čemu je posebno važan utjecaj nedorečenih i kontroverznih reformskih planova austrougarskog prijestolonasljednika Franje Ferdinanda.

Vladimir Dedijer smatra da je zamisao Franje Ferdinanda o uspostavi trijalizma, odnosno stvaranja posebne južnoslavenske jedinice unutar Austro-Ugarske sa središtem u Zagrebu, bila politička smicalica kojom je prijestolonasljednik htio pridobiti Hrvate i tako slomiti Mađare, zaobići dualistički okvir i obnoviti neku vrstu bečkog centralizma. Dedijer, isto kao i Seaton-Watson prije njega, uočava da su ove zamisli u Beogradu izgledale

59 Robin OKeY, Taming Balkan nationalism, New York, 2007., 211 - 216. Naime, nakon sastanka Vrhovne centralne uprave „Crne ruke“ na kojem je odlučeno da se atentatore zaustavi, poslane su instrukcije sarajevskom agentu Danilu Iliću. No, prema njegovim riječima, Princip i Grabež „nisu htjeli ni čuti o tome“ da se atentat obustavi. D. MACKInley, Apis: Congenial Conspirator, 136, 137; R. F. Hamilton, H. H. Herwig, Decision for war, 43.

60 Dušan T. BATA Ković, Slobodan Jovanović i Crna ruka, Slobodan Jovanović. Ličnost i delo., Naučni skupovi SANU knj. XC., Odeljenje društvenih nauka knj. 21, SANU, Beograd, 229, 230. 
opasno jer se vjerovalo da će stvaranje trijalizma onemogućiti da Srbija preuzme ulogu Pijemonta južnih Slavena. ${ }^{61}$

U tom je smislu karakteristično zapažanje Geoffreyja Wawaroa koji smatra da je Franjo Ferdinand iz srpske perspektive izgledao kao „zagovornik Velike Hrvatske, rimokatoličke super-države koja je trebala obuhvaćati Hrvatsku, Dalmaciju, Bosnu i Hercegovinu, Sloveniju ...čime je zagazio u pokrajine koje su Srbi smatrali svojima“.62

Robin Okey smatra da je „autoritarni nadvojvoda Franjo Ferdinand gajio dalekosežne planove da dvojbenim ustavnim manevrima presječe gordijevski čvor mađarskog... nacionalizma" pri čemu je austrougarska uprava u Bosni i Hercegovini, zbog širenja ideje da Srbija treba biti Pijemont južnih Slavena, gajila izraženo nepovjerenje prema Srbima. ${ }^{63}$

Iako Franjo Ferdinand nije bio ratoboran kako se to moglo zaključiti iz njegova strogog vojničkog držanja, iz perspektive Beograda njegove su zamisli izgledale opasno jer su stajale na putu ostvarenja ideje Velike Srbije na osnovu Načertanija Ilije Garašanina, što je bio zajednički strateški cilj Apisa i Pašića, posebno nakon Balkanskih ratova, kada je ta ideja izgledala na dohvat ruke. ${ }^{64}$ Usporedo s time, na Apisovo razmišljanje i djelovanje vjerojatno je utjecala i činjenica da je „Crna ruka“, prema riječima Dušana T. Batakovića, bila „kolateralna žrtva Balkanskih ratova“ u kojima su poginuli utjecajni članovi vodstva organizacije, ideolog i glavni utemeljitelj Ljuba JovanovićČupa, predsjednik Ilija Radivojević, bojnik Milan Vasić, koji je ujedno bio tajnik „Narodne obrane“, i mnogi drugi. Istovremeno, izvjestan broj članova bio je uvjeren da nema potrebe za daljnjim djelovanjem jer je njihova misija „osvetnika Kosova“ bila ispunjena. „Crna ruka“ je zato, smatra Bataković, „prestala djelovati kao jedinstvena i djelatna organizacija“ ${ }^{65}$

61 V. Dedijer, Sarajevo 1914., knj. I., 160 - 172, 196; R. W. Seaton-Watson, Sarajevo, 53 - 57.

62 Geoffrey Wawaro, A Mad Catastrophe, New York, 2014., 115.

63 R. OKeY, Taming Balkan nationalism, 248.

64 R. C. Hall, Serbia, 93, 94; D. Mackenzie, Apis: The Congenial Conspirator, 69, 70; M. MACMILAN, The War that Ended Peace, 402, 403.

65 D. T. BAtA Ković, Storm over Serbia, 332. Tezu o nefunkcionalnosti „Crne ruke“ nakon Balkanskih ratova na zanimljiv je način obrazložio još Čedomir A. Popović, član te organizacije i srbijanski pogranični časnik u Šapcu. Prema njegovu mišljenju, „Crna ruka“, osnovana 1911., nije se do izbijanja Balkanskih ratova sljedeće godine uspjela u cijelosti organizirati. Tijekom Balkanskih ratova, 1912. i 1913., zbog velikih žrtava popucale su organizacijske veze vodstva s članstvom, što znači da je u stvarnosti funkcioniralo samo vodstvo organizacije, tj. gore spomenuta šačica oficira okupljenih oko Apisa. Čedomir A. Popovıć, Sarajevski atentati organizacija Ujedinjenje ili smrt, Nova Evropa, knj. XXV., sv. 7, 1932., 399, 400. 
U ovakvim je okolnostima Apis, uživajući zaštitu šefa glavnog stožera srpske vojske feldmaršala Radomira Putnika koji ga je smatrao iskrenim domoljubom i vrhunskim protu-obavještajnim časnikom, $s$ malom skupinom od nekih 20 do 25 suradnika provodio vlastitu politiku, neovisnu od službene politike vlade u Beogradu. Zato je, doznavši za dolazak prestolonasljednika Franje Ferdinanda i za vojne manevre u okolici Sarajeva, zaključio kako je čitava stvar završna priprema za austrougarsku invaziju Srbije, odnosno da je rat neizbježan. ${ }^{66} \mathrm{U}$ tom smislu ironično zvuči zapažanje Margaret MacMillan i Mannfrieda Rauchensteinera da je Franjo Ferdinand djelovao kao kočničar ratobornog šefa austrougarskog glavnog stožera Conrada von Hötzendorfa jer je smatrao da eventualna vojna akcija protiv Srbije donosi rizik rata s Rusijom. ${ }^{67}$

Ipak, u najnovije vrijeme Mile Bjelajac istaknuo je kako je Apisov strah imao realno pokriće jer su austrougarski ratni planovi napad na Srbiju predviđali u trenutku kad ona bude najslabija. S obzirom na to da je 1914., nakon Balkanskih ratova, Srbija bila vojno i financijski iscrpljena i zauzeta gušenjem pobuna u južnim pokrajinama, Apis je vjerovao da su manevri austrougarske vojske, zakazani za lipanj 1914. u okolici Sarajeva, pokazatelj namjere Austro-Ugarske da iskoristi takvu situaciju, odnosno da su manevri „pretekst za upad Austrije u Srbiju, na čelu sa glavnokomandujućim Francom Ferdinandom“.68

O tadašnjem napetom ozračju u vrhovima vlasti Kraljevine Srbije svjedoči i podatak da je tijekom Prvog svjetskog rata Pašić „u trenutku iskrenosti...jednom talijanskom prijatelju priznao da je samo jednom strepio za budućnost svoje zemlje, kad je saznao za plan Franje Ferdinanda za preuređenje Austro-Ugarske monarhije“,69 što znači da je u proljeće i ljeto 1914. čak i pragmatični Nikola Pašić imao motiv prešutno odobravati planove Apisa i njegovih suradnika.

\section{KRALJEVINA SRBIJA I SARAJEVSKI ATENTAT}

Da je tome zaista tako svjedoči činjenica da je Gavrilo Princip na suđenju u Sarajevu u listopadu 1914. izjavio kako je jedan od njegovih suatentatora „Čabrinović ... rekao, da je njemu Tankosić kazao da taj kanal vodi direktno

66 $124-128$.

67 M. Macmilan, The War that ended Peace, 402, 403; M. Raucensteiner, The First World War and end of the Habsburg Monarchy, 79, 80.

68 M. BJelajac, Novi (stari) zapleti, 24, 26; Č. A. Popović, Sarajevski atentati organizacija Ujedinjenje ili smrt, Nova Evropa, knj. XXV., sv. 7, 1932., 406 - 408.

69 J. Remak, Sarajevo, 56, 57. 
od Beograda do Sarajeva. Znamo mi što se pod tim razumije: da su imali povjerenike“.70 Ovim je riječima Princip slikovito ilustrirao nikad do kraja razjašnjenu ulogu službenih vlasti Kraljevine Srbije u Sarajevskom atentatu. Naime, toliko puta spominjana činjenica da su trojica mladih atentatora u Beogradu od povjerenika „Crne ruke“ Milana Ciganovića dobili oružje, bombe, ali i izvjesnu svotu novca, samo je vrh ledenog brijega ovog problema jer je od Ciganovića linija zapovijedanja i odgovornosti vodila u dva smjera, prema „Crnoj ruci“ i Apisu, ali i prema Pašiću.

Milan Ciganović je s jedne strane bio posrednik između budućih sarajevskih atentatora i Vojina Tankosića, koji je za njih bio gotovo mitska figura jer je oličavao srbijanski vojno-zavjerenički milje povezan s četnicima, među kojima je bilo dosta dragovoljaca iz Bosne i Hercegovine. Jedan od takvih bio je i sam Ciganović koji je nakon četničke karijere dobio namještenje na srbijanskim državnim željeznicama, ali se i uključio u zavjereničku djelatnost u „Crnoj ruci“. Ciganović je Principa i njegove prijatelje uključio u dobro uhodanu zavjereničku mrežu nakon čega su oni počeli tražiti oružje za ostvarenje svog nauma. $S$ tom je namjerom jedan od budućih atentatora, Trifko Grabež, došao pred Tankosića. ${ }^{71}$

Gavrilo Princip je na sarajevskom procesu u listopadu 1914. taj susret opisao ovako:

„Tankosić je pozvao jednog od nas k sebi, a mi smo odlučili da podje Grabež.

Grabež mi je kazao da je Tankosić načinio na njega dobar utisak...“

„U koju je svrhu pozvao Tankosić jednog od vas“, upitao je Principa sudac.

„Da vidi da li smo sposobni da izvedemo atentat", odgovorio je Princip. ${ }^{72}$

Zavjereničko ozračje unutar "Crne ruke" i njezin odnos prema sarajevskom atentatu ilustriraju i riječi koje je Tankosić uputio Đuri Šarcu, drugom posredniku $s$ bosanskim atentatorima, predajući mu oružje za Principa, Čabrinovića i Grabeža: „Za slične svrhe ja sam dao do danas mnogo oružja, pa ne samo da nije ništa učinjeno, nego se nije ni pucanj čuo. Kad ti tvrdiš da je stvar na sigurnom putu, tada ne samo da ću ti dati oružje, već i samoga sebe. ${ }^{\text {“73 }}$

$\mathrm{U}$ isto vrijeme, Milan Ciganović je vrlo vjerojatno bio i agent predsjednika vlade Nikole Pašića, što znači što znači da je Pašić barem nekoliko mjeseci prije sarajevskog atentata moguće imao informacije iz prve ruke, što bi značilo da je, barem prešutno, odobravao zavjereničke planove bosanskih mladića, odnosno

70 V. BogićEvić, Sarajevski atentat, 75.

71 L. Pfeffer, Istraga o sarajevskom atentatu, 29; V. Dedijer, Sarajevo, knj. I, 376, 377, 385; David FromKIn, Europe's last summer, 122, 123.

72 V. BogićEvić, Sarajevski atentat, 59.

73 M. Belić, Komitski vojvoda Tankosić, 48. 
Apisa i „Crne ruke“. ${ }^{74}$ Zato je Ciganović, koji se uz Tankosića izričito spominje sarajevskoj policijskoj istrazi u ljeto 1914. i u austrougarskom ultimatumu Srbiji od 23. srpnja 1914., bio izuzet iz ograničenog broja uhićenja koja su po Pašićevu nalog bila izvedena nakon Sarajevskog atentata. Čak što više, Ciganović je vrlo brzo sklonjen iz Beograda, za razliku od Tankosića koji je bio uhićen i izložen policijskoj torturi. Razlog za Ciganovićevo sklanjanje vjerojatno je bila činjenica da je on bio rodom iz Bosne i Hercegovine te da je Austro-Ugarska mogla tražiti njegovo izručenje i tako doznati da su Pašić i njegovi ministri bili upućeni u pozadinu Sarajevskog atentata, ali i dobiti uvid u beogradsku obavještajnu mrežu u Bosni i Hercegovini. ${ }^{75} \mathrm{Uz}$ sve ovo, sumnju da je Ciganović zaista bio Pašićev agent potkrepljuje njegovo držanje na Solunskom procesu 1917. kada je svjedočio protiv Apisa i „Crne ruke“. O tome posredno svjedoče i sjećanja srbijanskog ministra obrane Dušana Stefanovića iz 1914. da je Pašić o pripremama za sarajevski atentat doznao po „izvjesnim privatnim dostavama“, vjerojatno upravo od Ciganovića. ${ }^{76}$

U prilog činjenici da su Pašić i njegovi suradnici imali informacije iz prve ruke govori i Vladimir Dedijer koji bilježi da je Pašićev najbliži suradnik Stojan Protić obavijest o kretanju sarajevskih atentatora najvjerojatnije dobio preko mreže „Narodne obrane“ čiji je povjerenik Jakov Miović, srpski seljak koji je živio s bosanske strane Drine i koji je radio za srbijansku vojno-obavještajnu službu, dakle za Apisa, odmah nakon prelaska sarajevskih atentatora o svemu izvijestio povjerenika "Narodne odbrane“ u Šapcu Božu Milanovića, koji je obavijest proslijedio svom nadređenom, šefu „Narodne odbrane“ Božidaru Jankoviću u Beogradu, koji je o svemu izvijestio Protića. ${ }^{77}$ Stoga ne čudi da je Protić, u dopisu

74 D. Fromkin, Europe's Last Summer, 125; C. Clark, The Sleepwalkers, 56, 385. Zanimljivo je spomenuti da je još B. Fay, pozivajući se na jedan članak iz novina La Federation Balkanique, Ciganovića nazvao „agentom provokatorom“ beogradske vlade. B. E. Schmitt također smatra da je Ciganović nesumnjivo bio dvostruku agent, samo upitnim smatra trenutak kada je ovaj bosanski emigrant, koji je isprva očito zdušno promisao ciljeve „Crne ruke“ i sudjelovao u Balkanskim ratovima, preuzeo tu ulogu. Čitavu stvar, smatra Schmitt, usložnjavaju dvojbe oko Ciganovićeva stvarnog identiteta, odnosno indicije da mu je pravo ime bilo Stevan Večerinac i da nije bio rodom iz Bosne i Hercegovine, nego iz Slavonije, točnije iz Vinkovaca. S. B. FAY, The Origins of the World War, vol II, 90, 146 - 148, 150 - 152, 156; B. E. Sснміт т, The Coming of the War 1914, volume I, 196, $218,219,436,464$.

75 S. B. FAY, The Origins of the World War vol II., 90, 146, 147, 150 - 152, 156, 550; B. E. SCHMITT, The Coming of the War 1914, volume I, 196, 218, 220, 235, 463; C. CLARK, The Sleepwalkers, 56, 385, 390, 455, 465, 467.

76 D. Mackenzie, Apis: The Congenial Conspirator, 188, 189; R. M. Draš Ković, Pretorijanske težnje u Srbiji, 185, 186; Đ. Đ. Stan Ković, Nikola Pašić, saveznici i stvaranje Jugoslavije, 29.

77 V. DEDIJER, Sarajevo 1914, knj. II, 103, 106. 
nastalom uoči Sarajevskog atentata, izrazio bojazan da će austrougarske vlasti razotkriti djelatnost beogradske obavještajne mreže jer je prebacivanje atentatora preko Drine obavljeno „nesmotreno, sa više lica, javno usred dana, bez ranijeg sporazuma i znanja policijskih vlasti“'. ${ }^{78}$

Iako Dedijer ove Protićeve riječi tumači kao dokaz da su beogradske vlasti bile neugodno iznenađene razvojem događaja, odnosno da nisu bile upoznate $s$ čitavim pothvatom, u njima je moguće iščitati i postojanje prešutnog, iako možda nevoljkog sporazuma vlade i Apisa. U tom smislu Protićeve riječi valja vidjeti kao odjek ozračja u vodstvu vladajuće Radikalne stranke, koje se nadalo da će se Apis i „Crna ruka“ zadovoljiti utjecajem u vojsci i da se neće miješati u vanjsku politiku. ${ }^{79}$

Ovdje je svakako važno spomenuti da je, prema spoznajama koje u najnovije vrijeme donosi povjesničar Vladimir Ilić, Nikola Pašić, kada je u razdoblju od 1905. do 1912. u više navrata bio ministar vanjskih poslova Srbije, sudjelovao u krijumčarenju oružja za četnike koji su djelovali u Makedoniji, ${ }^{80}$ zbog čega je za očekivati da je i kasnije bio dobro upućen $u$ tajne akcije koje su organizirane $u$ Beogradu, pa tako i u djelatnost „Crne ruke“.

$S$ tim u vezi, Andrej Mitrović, koji inače u potpunosti odbacuje bilo kakvu odgovornost Kraljevine Srbije za Sarajevski atentat, na osnovu uvida u objavljenu beogradsku arhivsku građu ističe kako se u vladinim krugovima već krajem svibnja i početkom lipnja 1914. znalo kada su atentatori, skupa s oružjem, prešli Drinu i stigli u Bosnu. ${ }^{81}$

Ako su Pašić i njegovi suradnici za pripreme za Sarajevski atentat zaista doznali tek krajem svibnja ili početkom lipnja 1914., onda je pogled na ulogu beogradskih vlasti nešto složeniji. Naime, ova su saznanja Pašića stavila u težak položaj u kojem je svaki potez koji bi povukao sa sobom nosio veliki politički rizik. Da je zaista pokuša zaustaviti zavjerenike mogao je, u trenutku kada je gotovo na vršku mača sačuvao premijersku stolicu, a možda i živu glavu, i kada se pripremao za nove izbore, očekivati novi udar „Crne ruke“, što mu svakako nije bilo u interesu. Zamisao da se o čitavoj stvari izvijesti austrougarske vlasti za sobom je vukla mogućnost razotkrivanja beogradske obavještajne mreže u Bosni i Hercegovini u kojoj su usporedno djelovali „Crna ruka“ i „Narodna obrana“ i kojom je od 1913., kao šef vojno-obavještajne službe, upravljao Apis. Da stvar

78 V. DediJeR, Sarajevo 1914, knj. II, 118.

79 V. Dedijer, Sarajevo 1914, knj. II, 92; O. Popović-Obradović, The Parliamentary system in Serbia 1903-1914, $602-608$.

80 Vladimir ILIć, Srpska četnička akcija 1903-1912, Beograd, 2006., 77.

81 A. Mitrović, Srbija u Prvom svetskom ratu, 37. 
bude gora, uspjeh atentata otvarao je mogućnost ratnog sukoba iscrpljene Srbije s Austro-Ugarskom, što je Pašić htio spriječiti ili barem odgoditi. ${ }^{82}$

U tom kontekstu valja promatrati vrlo neizravno upozorenje koje je srbijanski veleposlanik u Beču Jovan M. Jovanović 21. lipnja 1914. uputio austrougarskom ministru financija i upravitelju Bosne i Hercegovine Leonu Bilińskom. Jovanović je naime tada rekao da postoji opasnost da bi neki austrougarski vojnik srpskog podrijetla tijekom manevara u okolici Sarajeva mogao umjesto vježbovnim, zapucati bojevim metkom i ubiti prestolonasljednika Franju Ferdinanda. ${ }^{83}$ Dakle, ni riječi o atentatorima koji su krenuli iz Beograda za koje su Pašić i njegova vlada saznali barem od početka lipnja ni o beogradskoj obavještajnoj mreži koja je atentat omogućila i koja je u Bosni i Hercegovini djelovala od 1909.

\section{KRALJEVINA SRBIJA U ISTRAZI NAKON SARAJEVSKOG ATENTATA}

O ulozi Kraljevine Srbije u Sarajevskom atentatu svjedoči ključni dokument austrougarske istrage, izvješće koje je sredinom srpnja 1914. sačinio iz Beča posebno poslani činovnik ministarstva vanjskih poslova Friedrich von Wiesner. U tom izvješću, kako ga prenosi sarajevski sudac-istražitelj Leo Pfeffer, pisalo je sljedeće:,Elementi iz vremena prije atentata ne daju nikakve dokaze kojima bi se utvrdila propaganda vodjena od strane srpske vlade. Ali sam fakt da je ovaj pokret podržavan sa srpske strane, preko raznih udruženja, sačinjava, iako slab, ipak dovoljna osnov..." za daljnju istragu. ${ }^{84}$ Ove zaključke iz Wiesnerova izvješća, koje se može smatrati početkom razvoja događaja koji su vodili do austrougarskog ultimatuma Srbiji 23. srpnja 1914., Pfeffer je odbacio jer je smatrao „da se iz istražnog spisa o atentatu ne može ustanoviti veza sa zvaničnom Srbijom“ jer "nema apsolutno nikakovih dokaza da bi srpska vlada znala za atentat, ili za njegovu pripremu, kao ni za to da je ona pripremala oružje u tu svrhu. Naprotiv, ima mnogo elemenata kojima bi se moglo utvrditi mogućnost toga... Bombe su podrijetlom iz srpskih vojnih magazina, - to je izvan svake sumnje; ali se ničim ne dokazuje da su one...izdate iz tih magaziba ad hoc, jer

82 R. C. Hall, Serbia, 107; M. BJelajac, Novi (stari) zapleti, 22; O. Popović-Obradović, The Parliamentary system in Serbia, 463; D. T, BATA Ković, Storm over Serbia, 338, 339, 345.

83 V. Dedijer, Sarajevo 1914., knj. II, 123 - 130. Dušan Bataković ipak tvrdi da su Jovanoviću nedostajale pouzdane informacije o tome da su atentatori prešli Drinu pa je Bilińskom upozorenje prenio „na taktičan diplomatski način“, ali da ovaj „izgleda nije razumio važnost prijateljskog upozorenja i nije ga proslijedio caru i vladi u Beču“. D. T. BATA Ković, Storm over Serbia, 348.

84 L. PFEFFER, Istraga o sarajevskom atentatu, 98, 99. 
mogu poticati i od naoružanih komita. Izvjesne manifestacije poslije atentata upućuju na propagandu Narodne odbrane; tu ima dosta interesantnih elemenata za traganje..." ${ }^{\text {"85 }}$ Ovaj, načelni zaključak, među ostalim, prihvatili su R. W. SeatonWatson, Vladimir Dedijer i Joachim Remak. ${ }^{86}$

No, u najnovije je vrijeme austrijski povjesničar Mannfried Rauchensteiner ustvrdio da su iz Wiesnerova izvješća jugoslavenske vlasti iza 1918. izrezale početni dio u kojem je pisalo sljedeće „Na osnovu izjava koje su dali optuženi teško je dovesti u pitanje zaključak da je atentat pripremljen u Beogradu i da su pripreme za atentat umiješani srbijanski državni dužnosnici. Bombe su podrijetlom iz vojnog skladišta u Kragujevcu." Ipak, smatra Rauchensteiner, Wiesner je problem umiješanosti visoko rangiranih dužnosnika Kraljevine Srbije, posebno članova vlade, te pitanje o tome jesu li zavjerenici oružje dobili izravno iz srbijanskog državnog arsenala u Kragujevcu, ili na neki drugi način, uslijed nedostatka nepobitnih dokaza ostavio otvorenim..$^{87}$

U tom je smislu važno spomenuti da je još B. E. Schmitt istaknuo da je Wiesner u svom izviješću predložio da se od Kraljevine Srbije zatraži „zabranu svih srbijanskih državnih agencija koje su se bavile krijumčarenjem ljudi i robe preko granice, otpuštanje graničnih časnika osumnjičenih za sudjelovanje u zavjeri“ $i$ „sudbeni progon Ciganovića i Tankosića“. ${ }^{88}$ Ipak, Andrej Mitrović je, na osnovu istraživanja u bečkim arhivima, ustvrdio kako je u Wiesnerovu izvješću pisalo kako „nema mesta čak ni za sumnju“ da su službene vlasti Kraljevine Srbije bile umiješane u atentat, odnosno „postoji mnogo više razloga za tvrdnju da je to isključeno“ ${ }^{\text {89 }}$ Dvojbe koje iza sebe ostavlja Wiesnerovo izvješće dijelom je moguće razjasniti odgovorom na pitanje što i koliko su vlasti u Beču znale o djelatnosti „Crne ruke“.

Sarajevski sudac-istražitelj Pfeffer smatra da su austrougarske vlasti bile dobro upućene u djelatnost ove organizacije, ali da su je ignorirale iz političkodiplomatskih razloga, htjele su da službena istraga kompromitira „Narodnu odbranu“ jer je ova "bila u dobrim odnosima sa srpskim vlastima“. ${ }^{90}$ Isto tako i Joachim Remak smatra da su vlasti u Beču znale za "Crnu ruku“ i da su o njoj imali „iznenađujuće točne“ podatke koji međutim nisu upotrijebljeni u

L. PFEFFER, Istraga o sarajevskom atentatu, 99.

L. Pfeffer, Istraga o sarajevskom atentatu, 98, 99; V. Dedijer, Sarajevo 1914., knj. II, 164; R. W. Seaton-Watson, Sarajevo, 178; J. Remak, Sarajevo, 201.

M. Raucensteiner, The First World War and end of the Habsburg Monarchy, 103.

B. E. Schмiтt, The Coming of The War of 1914., volume I, 362, 363.

A. Mitrović, Srbija u prvom svetskom ratu, 17.

L. PFEFFER, Istraga o sarajevskom atentatu, 120 
službenoj istrazi, što on pripisuje njihovoj poslovičnoj „trapavosti“.91 Isto misli i Barbara Jelavich koja je, nakon uvida u arhivsku građu u Beču, došla do zaključka da su austrougarske vlasti „Crnu ruku“, čak i nakon sarajevskog atentata, vidjele isključivo kao prevratničku organizaciju kojoj je velikosrpska ideologija bila pokriće za njezine političke ciljeve unutar Srbije. Jelavich zato smatra da je, „iako su mnoge habsburške pritužbe bile opravdane“, neuspješan bio pokušaj austrougarskih vlasti da Srbiju u Europi prikažu kao opasnog i agresivnog susjeda. ${ }^{92}$

$\mathrm{Na}$ tom tragu Christopher Clark ističe da je na sve agresivnije držanje bečkog središta nakon smrti Franje Ferdinanda, osim otvorene potpore Njemačke, utjecalo i držanje službenih vlasti Kraljevine Srbije koje su nakon sarajevskog atentata u najboljem slučaju odugovlačili istragu. ${ }^{93}$ Ovo mišljenje dijeli i Margaret MacMillan koja smatra da se Nikola Pašić odlučio za taktiku sustavnog negiranja umiješanosti Srbije u sarajevski atentat što je dodatno potaklo ratobornost bečke elite koja je na tajnom sastanku održanom 19. srpnja 1914. dovršila tekst ultimatuma, koji je četiri dana kasnije službeno uručen vladi Srbije. ${ }^{94}$

Mannfried Raucensteiner pri tome ističe kako su političke elite u Beču na ovako odlučno držanje, među ostalim, bile potaknute i spoznajama sabranima u službenom spisu ministarstva vanjskih poslova „Povijest Srbije“, nastalom u razdoblju od 1908. do 1913., koje su učvrstile njihovo uvjerenje da se Srbiji ne može vjerovati, nego da treba pribjeći prijetnji ratom. ${ }^{95}$

91 Prema Remaku, da je ova istraga provedena detaljnije i da je ultimatum upućen Srbiji 23. srpnja 1914. započimao riječima „za smrt nadvojvode Franje Ferdinanda utvrđena je odgovornost tajnog srpskog udruženja zvanog Crna ruka i njenog vodećeg člana pukovnika Dimitrijevića, čije uhićenje zahtijevamo smjesta“, Srbija bi bila u puno gorem međunarodnom položaju, a Pašić bi bio prisiljen razotkriti srpsku obavještajnu mrežu u Bosni i Hercegovini. J. REM AK, Sarajevo, $204-206$.

92 Barbara Jelavich, What the Habsburg Goverment Knew about Black Hand, Austrian History Yearbook, svezak 22, 1991., 131 - 141.

93 C. Clark, The Sleepwalkes, 392 - 403, 412 - 455.

94 M. Macmillan, War that Ended Peace, 533, 534.

95 M. Raucensteiner, The First World War and end of the Habsburg Monarchy, 90 - 92. U pozadini ovakve odluke je, prema riječima Davida Stevensona, bila i činjenica da se prijeteća mobilizacija kojom u listopadu 1913. poduprt ultimatum Srbiji da napusti Albaniju pokazala preskupom pa je šef glavnog austrougarskog stožera Conrada smatrao da je kratki rat sa Srbijom bolje rješenje od ponovnih prijetećih mobilizacija. D. STEvenson, The Outbreak of the First World War, 6. 


\section{KRALJEVINA SRBIJA I AUSTROUGARSKI ULTIMATUM}

U Beogradu se, istovremeno, na čitavu stvar gledalo drugačije. Barbara Jelavich ističe da Pašićeva vlada nije mogla „dopustiti vanjsku istragu koja može razotkriti sve korake koji su doveli do atentata i mnoge druge optužbe “, ${ }^{\prime 6}$ vezane uz djelovanje „Narodne odbrane“ i „Crne ruke“. Stoga je u svom odgovoru na austrougarski ultimatum beogradska vlada 25. srpnja 1914., uz ostalo, ustvrdila kako nema dokaza kako je „Narodna odbrana“ ili bilo koja druga organizacija počinila kriminalni akt, obećavši da će uvažiti austrougarske zahtjeve i raspustiti svako društvo za koje se nešto takvo dokaže. ${ }^{97}$ Komentirajući ovo, Joachim Remak naglasio je da je iz perspektive Beograda težnja za stvaranjem Velike Srbije „bila vrijedna rata s Austrijom“i da je Srbija bila spremna riskirati rat jer se nadala pomoći Rusije. ${ }^{98}$

Christopher Clark i Hew Strachan smatraju da je na odlučnost vlade u Beogradu utjecala i činjenica da Francuska i Velika Britanija tijekom desetljeća koje je prethodilo sarajevskom atentatu, zbog rastuće savezničke povezanosti s Rusijom, nisu bile voljne pozornije slušati argumente iz Beča jer je, zbog strateških interesa, Austro-Ugarska unaprijed počela izgledati kao „agresor“, a Srbija kao „žrtva“.99

Stoga je, prema riječima Samuela R. Williamsona, beogradski odgovor, iako je zbog osvajanja simpatija Europe formuliran do krajnosti popustljivo, pažljivo zaobišao bit austrougarskog ultimatuma. ${ }^{100}$

Ovakvo držanje Beograda pokazuje da su Pašić i njegovi suradnici računali da vlada u Beču ništa pouzdano ne zna o organizaciji atentata. No, kao što je prethodno pokazano, u pozadini takvog držanja bile su i složene unutrašnje okolnosti u Kraljevini Srbiji, gdje su se pojedini utjecaji isprepletali i gdje je

96 B. Jelavich, Russia's Balkan Entanglements, Cambridge, 1991., 257.

97 C. Clark, The Sleepwalkers, 464.

98 J. REMAK, The Third Balkan War, 365.

99 Christopher Clark, nakon uvida u službene dokumente britanske vlade, ističe kako je Velika Britanija na Balkanske ratove gledala „kroz geopolitičke leće sistema saveza“ u Europi, pri čemu je Srbija izgledala „kao prijateljska država angažirana u viteškoj borbi sa zastrašujućom AustroUgarskom“. Zbog toga su, smatra Clark, sustavno zataškavana izvješća britanskih konzula o zločinima koje je srpska vojska počinila na Kosovu i u Makedoniji. C. CLARK, The Sleepwalkers, 44, 45.; Hew Strachan u tom smislu navodi primjer krize oko albanske granice krajem 1913., kada su Francuska, Velika Britanija i Rusija mirno gledale kako Srbija krši međunarodne ugovore i kada je Austro-Ugarska sama, ultimatumom, prisilila Srbiju da se istih ugovora drži. H. STRACHAN, The First World War, 56, 57

100 S. R. Williamson, The Origins of World War I, 812. 
teško, možda čak i nemoguće, među njima napraviti jasnu razdjelnicu. ${ }^{101}$ Zato se opravdanim čini stajalište Samuela R. Williamsona i Ernsta R. Maya koji tvrde da su srbijanske vlasti znale za zavjeru, ali je nisu zaustavile. Uhvaćeni $\mathrm{u}$ intenzivni sraz s vojskom, članovi vlade nisu mogli spriječiti Apisa bez da razotkriju vlastitu krivnju. ${ }^{102}$

Dakle, u pozadini svega nije bilo, kako se to često tvrdi, isključivo držanje agresivnijeg dijela bečkog vojno-političkog vrha koji je predvodio šef austrougarskog glavnog stožera Conrad von Hötzendorf i koji je smatrao da je cilj ultimatuma od 23. srpnja 1914. inscenirati lokalni rat sa Srbijom. Sadržaj ultimatuma je, kao i prethodno provedena istraga te kasniji sarajevski sudski proces, pokazao da su vlasti u Beogradu nastojale sakriti svoju obavještajnu mrežu koja je omogućila Sarajevski atentat.

Vladimir Dedijer smatra da je isticanje Sarajevskog atentata kao osnovnog ili neposrednog uzroka izbijanja Prvog svjetskog rata pretjerivanje jer su atentatu važnost dale nerazriješene napetosti u Europi. ${ }^{103} \mathrm{U}$ tom smislu i Richard C. Hall ističe da sarajevski atentat sam za sebe nije bio uzrok ničega te ključnim smatra način na koji ga je Austro-Ugarska upotrijebila, odnosno austrougarski ultimatum Srbiji od 23. srpnja za koji smatra da je potaknuo političku krizu koja je dovela do izbijanja rata. ${ }^{104}$

Ovakav način gledanja zanemaruje činjenicu da je vlada u Beogradu u donošenju političkih odluka samo do određene mjere prihvaćala vanjske pritiske, odnosno da je odluke donosila u kontekstu unutrašnjih političkih sukoba i u skladu sa strateškim gledanjima premijera Nikole Pašića koji je računao na potporu Rusije i koji je u svom odgovoru na austrougarski ultimatum pažljivo zaobišao bitne zahtjeve Beča. U tom smislu, ističe Jack S. Levy, „Srbija je davala prednost kontinentalnom ratu uz potporu Rusije, nasuprot lokalnom ratu sa Austro-Ugarskom, ali je njena uloga u širenju rata zanemariva". ${ }^{105}$

Ovaj apokaliptični pogled na držanje Srbije u srpnju 1914. podupiru i zapažanja povjesničara Đorđa B. Stankovića prema kojem su Pašić i vojni krugovi u Beogradu još 17. srpnja 1914. zaključili kako se oružani sukob Austro-Ugarske

101 U tom smislu Olga Popović-Obradović ističe da je u predvečerje Prvog svjetskog rata do vrhunca došla dugogodišnja praksa političkog pogađanja između beogradske vlade i „Crne ruke“ zbog čega je teško vjerovati da Pašić i njegovi suradnici nisu imali podrobnije spoznaje Apisovoj djelatnosti i njegovim planovima. O. Popović-OBRadović, The Paliamentary system in Serbia, 588.

102 Samuel R. Williamson, Ernst R. MaY, An Identity of Opinion. Historians and July 1914., The Journal of Modern History, svezak 79, 2007., br. 2, 353.

103 V. Dedijer, Sarajevo 1914., knj. II, 238.

104 R. C. HALL, Serbia, 110.

105 J. S. LEvy, Preferences, constraints and choices in July 1914., 156, 157. 
i Srbije neće moći lokalizirati, odnosno da će čitava stvar biti razriješena ratom među velikim silama. ${ }^{106}$

Zato se, na kraju, treba složiti s Jackom S. Levyjem, F. F. Hamiltonom i H. H. Herwigom da uloga Kraljevine Srbije u stvaranju povoda za izbijanje krize koje je dovela do izbijanja Prvog svjetskog rata nije bila odlučujuća, ali nije bila ni zanemariva. Posebno zato što su srbijanski politički vođe, slično kao i politički vođe u drugim europskim zemljama koje su se uskoro našle u ratu, „bili svjesni rizika, da je širi sukob vjerojatan...“, ali su ipak „poduzimali političke inicijative za koje su znali da će vjerojatno dovesti do rata“. ${ }^{107}$

\section{ZAKLJUČAK}

Uloga Kraljevine Srbije u Sarajevskom atentatu i izbijanju Prvog svjetskog rata još je uvijek predmet kontroverzi, zbog čega je bilo važno prihvatiti tezu povjesničara Seana McMeekina i na osnovu raspoloživih spoznaja ocijeniti „razinu odgovornosti“ službenih vlasti u Beogradu. Najvažnija sastavnica (su) odgovornosti Kraljevine Srbije svakako je beogradska obavještajna mreža koja je nakon Aneksijske krize 1908. i 1909. uspostavljena u Bosni i Hercegovini, a u koju su bili uključeni „Narodna odbrana“, srbijanska vojno-obavještajna služba, „Crna ruka“, ali i pripadnici „Mlade Bosne“.

Predsjednik beogradske vlade Nikola Pašić i njegovi suradnici imali su manjeviše jasan uvid u djelatnosti ne samo „Narodne odbrane“, koja je ionako bila pod njihovim nadzorom, nego i u djelatnost "Crne ruke“ s kojom su, usprkos opasnim međusobnim sukobima, dijelili privrženost velikosrpskom političkom programu izloženom u Načertaniju Ilije Garašanina. U tom smislu sukob Pašića i Apisa, odnosno „Crne ruke“, koji je kulminirao nedugo prije Sarajevskog atentata, treba promatrati kao sukob oko vlasti, ali i oko taktičkog pitanja realizacije zajedničkog cilja, što je uključivalo dvojbe oko potencijalno vrlo opasnog rata $s$ Austro-Ugarskom, a ne kao sredstvo kojim bi se post festum skinula odgovornost $s$ Pašića i njegove vlade.

S tim u vezi važno je istaknuti da su se i Pašić i Apis, ali i mladobosanci koji su atentat izveli, bojali nedorečenih reformskih zamisli austrougarskog prijestolonasljednika Franje Ferdinanda pri čemu je najveću odbojnost i strah izazivao trijalizam koji bi ne samo zaustavio realizaciju Velike Srbije, nego bi 
na duge staze djelovao kao sredstvo apsorpcije Srbije u preuređenu monarhiju Habsburgovaca. U tom kontekstu, ali i u kontekstu vrlo napetih odnosa između Srbije i Austro-Ugarske, posjet Franje Ferdinanda Bosni i Hercegovini u lipnju 1914. i vojni manevri koji su tamo održani u Apisovim očima izgledali su kao predigra za otvorenu vojnu agresiju Austro-Ugarske na Srbiju. U takvoj situaciji bosanski su mladići, koji su po Beogradu tražili potporu za svoju zamisao o atentatu austrougarskog prijestolonasljednika, izgledali kao logično sredstvo za odbijanje prijetnje koja je izgledala vrlo realno.

Nakon Sarajevskog atentata beogradska vlada nije imala puno izbora jer Pašić nije mogao, a ni htio provesti detaljnu istragu koju je tražio Beč jer se bojao „Crne ruke“ i jer bi time bila razotkrivena beogradska obavještajna mreža. Jedino što mu je preostalo bila je taktika zataškavanja činjenice da su on i njegovi suradnici za namjere atentatora i njihovih beogradskih sponzora znali barem od kraja svibnja 1914., dakle mjesec dana prije atentata, i da nisu napravili konkretan napor da atentat spriječe. Ipak, Pašićeva taktika zataškavanja ne bi bila moguća da nije bilo, kako to kaže Joachim Remak, „trapavosti“ austrougarskih vlasti koje nisu pričekale da se istraga o Sarajevskom atentatu provede do kraja, nego su za sastavljanje ultimatuma Srbiji odlučile inzistirati na nedovoljno istraženim činjenicama. Zato su Pašić i njegovi suradnici mogli računali da Beč nema ključne informacije o pozadini Sarajevskog atentata i nadati se da će politikom otezanja prikriti svoju stvarnu ulogu.

Zato na kraju valja ustvrditi da se razina odgovornosti Kraljevine Srbije za Sarajevski atentat i izbijanje Prvog svjetskog rata ogleda ponajprije u postajanju terorističko-obavještajne mreže čiji su konci sezali od službenog Beograda, preko Drine u Bosnu i Hercegovinu. Djelatnici ove mreže u najmanju su ruku bili suorganizatori Sarajevskog atentata za koji su Nikola Pašić i njegovi suradnici znali vjerojatno već početkom 1914., a u najmanju ruku od kraja svibnja 1914., ali nisu, zbog političkih i ideoloških razloga, učinili ništa da ga spriječe. Stoga im nakon atentata nije preostalo ništa drugo nego zataškavati i negirati svoj dio odgovornosti za krizu koja je uslijedila. 
Tihomir RAJČIĆ

\section{THE ROLE OF THE KINGDOM OF SERBIA IN THE ASSASSINATION IN SARAJEVO AND THE OUTBURST OF WORLD WAR ONE}

\section{SUMMARY}

In this paper, the author tackles the issue of the role of the Kingdom of Serbia in the assassination in Sarajevo and the outburst of World War One, this issue still being a rather pressing matter. The author primarily examined the Belgrade intelligence web in Bosnia and Herzegovina, into which threads of the government in Belgrade, its organisation "National Defence", as well as organisations that were not under its direct control - the "Black Hand" and "Young Bosnia" - were interwoven. It is characteristic for all of them that they feared the incomplete and controversial reform ideas of Franz Ferdinand, Austro-Hungarian heir to the throne, whereby trialism provoked the most aversion and fear; in the words of Geoffrey Wawaro, the Serbian party saw this as the creation of the "Great Croatia, Roman-Catholic super-state". This would have not only put a stop to the realization of the Greater Serbia, but also, for a longer term, initiated the process of the absorption of Serbia in the reconstructed Habsburg Monarchy.

After the assassination in Sarajevo, the government in Belgrade did not have much choice. Pašić neither could nor wanted to conduct a thorough investigation as demanded by the government in Vienna. Since he dreaded Apis and the "Black Hand", and since this would have disclosed the Belgrade intelligence web, the only thing that remained was the cover-up tactics. Thus, the level of liability of the Kingdom of Serbia for the assassination in Sarajevo and the outburst of World War One reflects itself first and foremost in creating a terrorist intelligence web and covering up the co-liability for European crisis, which exploded following the assassination in Sarajevo.

Keywords: Kingdom of Serbia; assasination in Sarajevo; Belgrade intelligence web; Franz Ferdinand. 
